\title{
Status and Perspectives Livestock Production: The Case Region Polimlje-lbar
}

\author{
Goran Rajović ${ }^{1, *}$, Jelisavka Bulatović ${ }^{2, * *}$ \\ ${ }^{1}$ Street Vojvode Stepe 252, Belgrade, Serbia \\ Phone: 0038161/19-24-850 \\ ${ }^{2}$ Department of Textile Design, College of Technology and Management, \\ Street Starine Novaka 24, Belgrade, Serbia \\ Phone: 003861/ 3082651

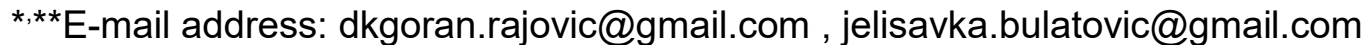

\begin{abstract}
In production structure of agriculture in the region Polimlje-Ibar, livestock production has a very important role, because without a stable and developed livestock production has neither developed agriculture. Therefore, in this paper, shows the number of livestock by type and category. Unsatisfactory number of livestock in the region, is primarily the result of economic factors, such as reduced local and regional markets, low purchasing power, transition, privatization, lack of long-term strategies for animal husbandry development, technological and technical unwillingness processing facilities, primary production disorganization, poor farmers and processors association, insufficient and slow recovery racial composition of cattle. In structure of use agricultural areas in the region, stands out the predominantly pasture type of agricultural land with higher participation of meadows $\left(\mathrm{P}_{4} \mathrm{~L}_{2}\right)$. The structure use in livestock production has characterized by the direction with prevailing participation sheep farming and greater participation bovines $\left(\mathrm{O}_{4} \mathrm{G}_{2}\right)$. Judging by the number and categories of livestock by type, production volume, as well as other indicators, livestock production in the region generally, serves to meet the needs of the household. A smaller part is intended market. In order that problems were solved in an appropriate manner, it is necessary to adopt appropriate strategies in livestock region Polimlje-Ibar, with the development of the proposed measures, which must be long term, because only in this way can stop the decline in the number of cattle to provide the increase livestock production and improve the quality of livestock products.
\end{abstract}

Keywords: Region Polimlje-Ibar; livestock; status; perspectives

\section{INTRODUCTION}

Region Polimlje-Ibar is a geographical unit which comprises $20.6 \%$ of the total area of Montenegro $\left(13.812 \mathrm{~km}^{2}\right)$, or on the territory living $18.96 \%$ of the population compared to the total population of Montenegro in 2003 (673.094). A surface area of $2842 \mathrm{~km}^{2}$ at which is the list of population from the 2003, live 127.635 inhabitants or 44.9 inhabitants / $\mathrm{km}^{2}$ [1]. 


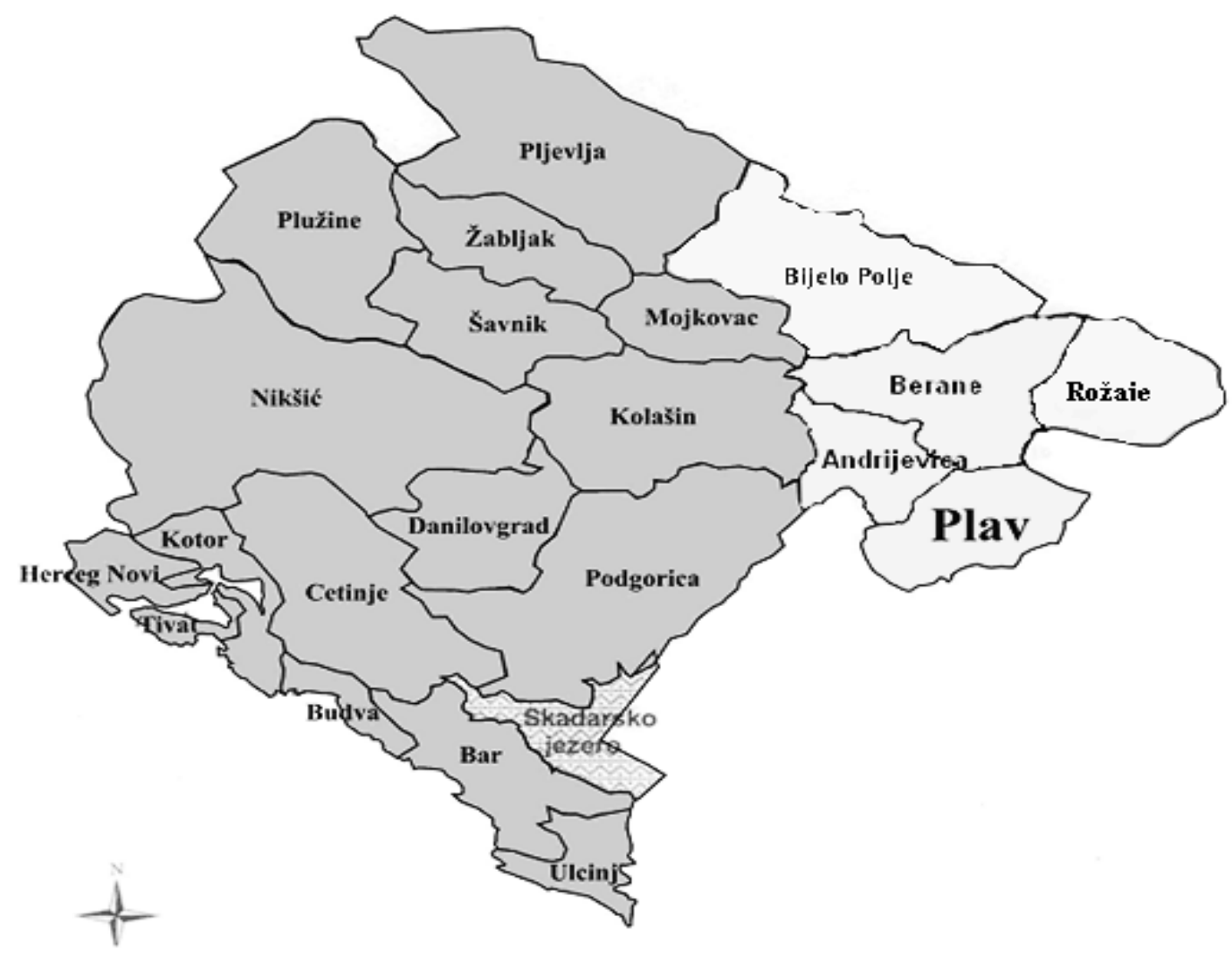

Figure 1. Region Polimlje-Ibar on the map of Montenegro [7-9].

Natural resources (land and forest) and its qualitative characteristics are favorable for the livestock development in region Polimlje-Ibar. However, analysis of research below shows that agriculture in the region does not comply with all to the available natural and social conditions. The territory of the region Polimlje-Ibar insufficient attention have was paid to the problems of agricultural development, especially the choice of the optimal structure of production. In addition, so far way management (small plots, outdated processing land, and uncoordinated structure of production) is not in function development of agriculture. Greater respect of agriculture as a primary activity, provide the opportunity to take advantage of comparative advantages of the region [2-3]. Our research records, based on similar studies Arsić et al [4], emphasize the foreground in the organic component of livestock production in the region. In fact, in all branches cattle breeding, there is considerable potential for the development of organic livestock production, where is due to the depopulation trend have occurred to partial disappearance agricultural activities, so it is not realized the development of intensive production. Code bovines and of sheep traditionally prevails holding animal on pastures and preserved traditional production of autochthonous species of dairy products (cheese and cream cheese), which encourages the development of organic livestock production. Great potential is the presence of large areas of meadows and pastures that been not used rationally, due to insufficient number of cattle. Very distinct resistance of indigenous breed is animal in the region Polimlje-Ibar allows their growing without any major 
investments in health the protection and treatment, and in this manner getting animal products of special quality for human consumption, not containing the residue different antibiotics and plant protection agents.

In recent years, interest has grown considerably for organic agriculture, in response to the increasingly obvious environmental degradation, deterioration in the quality of food and all greater jeopardizing health of the human population. The constant growth in demand for organic products in the world indicates that this production method can be very profitable, if you properly use natural resources, knowledge and production experience [5-6].

\section{RESEARCH METHODOLOGY}

Two main groups of data sources been used in the study. The first group includes sources of statistical data on the number of livestock by types and categories available since the Statistical Office of Montenegro. The second group includes the results of previous studies as well as survey data on livestock production, are available from the livestock farms in the region, Agro-marketing system of Montenegro and the Agency for Development of Small and Medium Enterprises in Montenegro. The focus of the research based been based on an analysis of the situation and prospects of development of livestock: sheep, cattle, poultry, pig, goat, horses and beekeeping, whereby are consciously ignored the other, underrepresented branches livestock. Have been studied and are written sources on the internet. In the context of agro-geographical study of agriculture, we applied the method alternating dividers in the system 6/6, worked out at the Institute of Geography, Polish Academy of Sciences Kostrovicki [10-11]. This method determines the orientation of agricultural production [12]. Review of the literature and concepts within the agrarian structure as well as procedure application rate the method "kolejnih ilorazow" (alternating dividers) gives and Tyszkiewicz [13]. In the text was applied method analyzes and method of synthesis modeled on the research Jatau [14], Tsegha [15], Aleshi [16], Owa [17], Bjelajac et. al. [18].

\section{RESULTS AND DISCUSSION}

Statistical data on the movement of livestock and agricultural production is difficult to obtain due to lack of proper statistical material. In other words, it means that the statistics do not pay enough attention to the condition of livestock and livestock production, and without such material is impossible to give view the overall agricultural production. For this reason when displayed livestock we must use information obtained from cattle farms in the region, which will be processed based on the data of the Statistical Office of Montenegro [19].

Before we approach presentation the current state of livestock in the region PolimljeIbar, it is important to emphasize that cattle breeding represents a significant potential for agricultural development in the region, but is underdeveloped in relation to natural resources and the demands of intensive agricultural production. Namely, level of livestock production does not meet potentials, which to her natural advantages in the territory of the Region provide. There are several reasons for this: first, dominated by small, farms that do not provide opportunities for higher volume production. There are several reasons for this: first, mostly small, divided agricultural holdings that do not provide opportunities for higher levels of production machinery are old. Depopulation of villages and aging agricultural population, reduced use of agro-technical measures, the lack of industrial facilities for the processing of agricultural raw materials, there is also and the problem failure to comply with the required 
quality standards in the livestock production and poor connections and organization in market approach of individual agricultural producers [20].

Taking into account the natural resources of the region and the fact that the meadow and pasture participate with $85.61 \%(109.596 \mathrm{ha})$ in the total agricultural land surface (128.012 ha), cattle breeding should be the main source of agricultural production. In order to get an adequate picture the structure of agricultural land in the region Polimlje-Ibar, applied is a method in a system alternating dividers $6 / 6$, and we have found following the direction of agricultural land use: $\mathrm{P}_{4} \mathrm{~L}_{2}$ - Mostly pasture direction of agricultural land with a higher share of meadows ${ }^{1}$. The overall structure of agricultural land, besides the aforementioned meadows and pastures, participate arable land and gardens with 14.828 ha or $11.58 \%$, orchards 3.588 ha or $2.80 \%$.

The region Polimlje-Ibar agricultural holdings are breeding 97.953 chickens, 88.229 of sheep and 40.800 bovine animals. In the structure of the livestock, participation pig is a little 3.854 animals. There are two reasons for this: lack of pig farms and non-use of pork in the diet of the Muslim population. By applying method-alternating dividers in the system $6 / 6$, we identified in the region Polimlje-Ibar in 2005, following the direction of livestock: $\mathrm{O}_{4} \mathrm{G}_{2}-$ Direction with prevailing participation of sheep and greater participation bovines ${ }^{2}$.

Sheep farming is the most significant number of individual's cattle breeding activity in the region. Development of sheep is also, determined and needs for wool in the domestic handicrafts. The total number of sheep in the region in 2005 amounted to 88.229 the throat. Inadequate sheep breeding in the region, explain the fact that, due to: lack of labor, poor economic conditions, and ways animal husbandry, disposal of slaughter lambs with a small measure weight to $15 \mathrm{~kg}$, the adversely reflected of profitability of production, low purchase price of lambs, of sheep, raw leather and wool [21]. Number the throat of sheep per unit of agricultural area amounted to 0.69 head / ha. Racial composition sheep is very unfavorable. Sheep agricultural unit was 0.69 head / ha. The racial composition dominated mainly two kinds: of ore and mountain "pramenka". Growing of sheep usually is related to the own needs, so that are surpluses negligible. The largest part of the of market surpluses, according to tradition, is sold at markets or selling intermediaries. According to survey estimates of in 2005, the production of sheep milk amounted to about 37 liters per one sheep during the year. Much of sheep milk is process in households alone or together with cow's milk, the cheeses of varying quality. Average yields wool per sheep in 2005 are very low and amount to about 1.2 $\mathrm{kg}$. The largest part of the wool produced have used in domestic industries; a much smaller part is placed on the market. "The tradition of sheep breeding should support, and improved. Unfavorable situation in sheep breeding may be change by raising sheep farms increased processing of meat and dairy products, and development of cottage industry based on wool...

Prerequisite for raising farm is to improve forage production, construction of facilities for the sheep, equip these facilities modern techniques and providing veterinary protection. Overall sheep are breeding of the course and bovines should that monitor and facilities for their processing (abattoirs, processing centers, dairies, mills), where they are produce good quality products (cheese, cream cheese, prosciutto, products from wool)" [22]. The construction of 2001 sheep farms "Korać" in Bijelo Polje, should certainly uphold. Namely, this farm is 2001 started with six of breeding sheep, already in 2009 year; it had over 1,000 sheep in the flock. Application of modern technology in collaboration with professional and academic institutions, "Farm Korać" produce quality lambs for breeding and slaughter carried out synchronization estrus and artificial insemination for the off-season lambing. The farm has a semi-intensive character of production. Much of nutrients for winter meal are farm

\footnotetext{
${ }^{1}$ The variables and their symbols used in the formula: O-arable land, V-Orchards, L-Meadows, P-Pastures.

${ }^{2}$ The variables and their symbols used in the formula: G-cattle, S-pig, O-sheep.
} 
provides from their own and leased agricultural area (21ha), products hay, grass and maize silage as well as concentrated food.

A cattle farming is by number of heads the second activity livestock in the region. The number of heads of cattle in 2005 amounted to 40.800. Cattle are the highest breeding for getting milk, dairy products and meat, as well as for obtaining of organic fertilizer. In breeds of beef cattle dominate, according to estimates of the Biotechnical Institute in Podgorica, various crossbreds about $50 \%$ of the total cattle population. Tyrol Grey bovine accounted for about $15 \%$, while highly productive breed's bovine animals Holstein and brown bovine animals together represented with about $32 \%$. Milk production in 2005 amounted to about 1.2771 per cow. Low milk yield of cows is the result of racial composition and inadequate nutrition. Production of beef meat (all categories) is having estimated at about $80 \mathrm{~kg}$ by cows. The above data indicate that, irrespective of the favorable climatic conditions in the region, cattle breeding not at satisfactory level. Until of such processes, there was variety of reasons. Primary forage and today consists of small meadow hay, straw and cornstalk. On arable land are not achieved significant results in the production animal feed, without which it is not possible to increase the productivity bovines. Considering that, the existing pastures in very poor condition, for successful development of cattle in the region, it is necessary to solve the problem forage base and improve the botanical composition of pastures [22]. Most of the cattle is grown on small soils and for breeders personal needs, so that institutional support (improved genetic structure, investment safety, development adequate and certified processing capacity, training of farmers) is necessary, regardless of whether coming from the state, local government or international donor programs (UN, USAID, EAR) [23].

Continuous improvement of milk production, not only its quantity but also the quality, has to be one of the most important goals when it comes to livestock development in the region. This is especially important if one takes into account that in most household's milk used for cheese production, while smaller quantities delivered to dairies. Given the importance of cheese production in the Region, Simmental bovines would be the most important race intended for obtaining high-quality milk, whose purpose was primarily the processing of cheese and milk cream, because this breed bovines with high milk yield has and a large amount of milk fat and protein in the milk. The main objective of the livestock production in the region is intensifying the production of milk and meat. In addition to the genetic factors, which are expressed through specific breed characteristics, milk production affect both environmental factors, most notably diet and housing conditions. Nutrition is having based on the use of forages obtained from natural meadows and pastures...During the summer month's bovines the feed the on pasture with the use small amounts of concentrated feed. During the winter, nutrition is having based on the utilization of meadow hay and concentrate) [23]. The construction 2006 livestock farms "France" in Bijelo Polje, should certainly have be supported. Specifically, farm „Franca" for fattening steers, is the first of this type built in Montenegro. Capacity of the farm, currently stands at 500 beef cattle and represents one of the most important agro-industrial companies in the region. An important segment business enterprise is of marketing surpluses. Together with company "Meat Turnover", the farm realized project "Fattening steers" in cooperation with 17 subcontractors", which fattening 1.300 beef cattle. In this manner, the farm provides powerful contribution to the development of primary production the development of family business in rural areas. 
Table 1. Number of livestock in 2005.

\begin{tabular}{|c||c|}
\hline Types of livestock & Number \\
\hline Cattle & 40.800 \\
\hline Sheep & 88.229 \\
\hline Pigs & 3.854 \\
\hline \hline Horses & 3.287 \\
\hline Poultry & 97.953 \\
\hline Beehives & 13.073 \\
\hline
\end{tabular}

Source: Statistical Office of Montenegro [19], Census of Agriculture, data calculations by the author.

Poultry rising is an important livestock activity. Judging by that that, at least at first glance, the market in the region, good stocked poultry with meat and eggs, gain the impression that the, when the production is concerned, there is no problem.

However, according to Škorić [24], the annual production of poultry meat per capita ranges between 6 to 8 kilograms per year and consumption of eggs from 130 to 150 pieces. In developed countries, of the total consumption two-thirds of the eggs is used in the industry of pasta and confectionery industry, in the production of mayonnaise and other forms of consumption, as semi-products, while the rest of in general consumption, while in our country egg is still used exclusively in the shell. Globally, the based on data on the number of poultry and production of poultry meat, are clearly perceive numerous factors, which have adversely affected the poultry production. Most importantly, according to Škorić [24] state of farms in technical and technological terms, dependence on imports of genetic material and the lack of programmed (planned) imports of the same. The dependence than imports of components for feeding poultry, as well as of vitamin mineral supplements, the lack of long-term development policy poultry production, lack production planning and poor organization, narrowed market, the inability to export, Business conditions (expressed instability), expressed concern and the populist print media reporting after the occurrence of avian influenza. Also, the production is in large part is still takes place on farms who stare by several decades, with outdated equipment and fleet management, high maintenance costs, which cost price a significant burden and prevents use of the genetic potential of highly productive and paid expensive poultry imports. As a separate issue, to be considered the existence of all zoo hygienic and technological conditions on the farm. Producers in the region, most lacking are the source of quality financing development projects and improving technology.

Other types of livestock are not in harmony with the natural capabilities of the region. One of these is the pig breeding. Number of pigs in 2005 amounted to 3.854. In racial composition of the pig are prevalent: domestic a white the fleshy pig, Yorkshire, Dutch and Swedish Landrace. Growing pigs usually related to their own needs, with quite small production for the market. Very varied growing pigs without greater control and management accountants, characterize pig production unstable market with frequently falls price, unstable and unprofitable production. Breeding and feeding pigs and almost that it was a private sector is very diverse, with no production plan and controlled feeding. In the region, there is no economic interested in the long run for growing pigs, except for rural households with occasional market surpluses. Just such a situation requires establishing control of breeding, 
selection, better of nutrition and introducing new biotechnological processes to maximize the number of sows inseminated, intensification and the introduction of selection and qualitatively and quantitatively rapid development of pig breeding in the private sector and in rural areas [25]. Especially, which has today reached the level the productivity of pig for which the almost was considered to that biological limited. Namely per sow per year is obtained 26 of piglets 1.800 to $2.000 \mathrm{~kg}$ live weight, 1.450 to $1.620 \mathrm{~kg}$ of meat and 900 to $1.010 \mathrm{~kg}$ of meat. Number of fattening pigs per sow per year reaches the digit of 25 . Addition to this, in today's contemporary conditions, there is an effective breeding and selection work with accurate estimates breeding hens values animals, where each farmer depending on the aim of his production. Whether it be an in this case an increase in daily gain and meat quality or increasing the percentage of meat and conformations, could buy an appropriate genetic material. Number of fattening pigs per sow per year reaches the digit of 25 . Addition to this, in today's contemporary conditions, there is an effective breeding and selection work with accurate estimates breeding hens values animals, where each farmer depending on the aim of his production. Whether it be an in this case an increase in daily gain and meat quality or increasing the percentage of meat and conformations, could buy an appropriate genetic material. Rapid spread desirable genetic basis of goes in the direction that is of one quality of boars applying technology of artificial insemination may annual receive up 3.000 of piglets and that the index of reproduction sows 2.2 to 2.4 times annual, which ensures constant increase production [26]. For larger volume of pork production in the region, there are very good conditions: tradition-which is a very important foundation for commercial production, production animal feed (corn, barley, and soybean, sunflower) - as the basis of pig production, enough available surfaces for the use of manure and environmental protection from pollution. Labor force in large numbers, as well as with a lot of experience the where are quality and professional cattleman cornerstone in swine production, needs and opportunities for the production of safe food production [26].

Statistical Office of Montenegro not recorded as goat breeding sector of livestock production. So it does not we have information on the number of goats in the region. Passing a law to ban the keeping of goats (1954), the number of these very profitable animals, began rapidly to diminish, that would goats, almost, disappeared from the mountain pastures. Damages that caused by this, no one is tried to calculate, and probably that is impossible, because they are priceless. Took a long time, to establish that the damage caused by goats, represent the insignificant problem compared to the destruction of forests by man. Injustice done goats, corrected in 1984, when he again legalized the keeping of goats. She stopped are being persecuted the titleholders goats. In the previous period, a large part of the pasture areas has stood neglected, because in addition to goats, other farm animals, there is no possibility to use them [27]. According to free valuation, in this region in 2005 are no more than 80-100 goats. However, encouraging is the fact that there is more and more interested individual breeders for breeding goats. Natural options for growing goats in the region are very pronounced; however, there is no organized model of goat breeding. Breed composition is unsatisfactory, so that the effect is less than a goat breeding possible. In terms of racial composition, populations of goats in the region have roughly divided into three groups: noble race (mostly Alpine and "Sanska" sporadically), animals in the type of noble breed (domestic Balkan goat with more varieties according color) and crosses of (through unplanned crossing different varieties of domestic Balkan goat and "istihsa"- of noble breed). According to the results of the Biotechnical Institute in Podgorica, the average milk production per goat is about 140 , and the average production of meat, about $15 \mathrm{~kg}$ [28]. Goat's milk and goat's milk products the known as users of health. These products are easy to digest, have a high nutritional value and medicinal properties. They then used as food for the prevention and therapy of disease remission. Consuming of these products strengthens immunity, disease 
resistance, ensures a rapid growth optimal body weight, improved bone mineralization ...Conducted research shows that that goat's milk contains anti-cancer properties. On the other hand, goat meat contains low of fat, easy to digest, good taste and is an alternative to chicken and fish [29]. Goat breeding could be important due to the additional production of household income, because in addition to the milk, cheese, goats can produce twice as much of the skin, as compared to other ruminants. In addition, goats are the most prolific cud (playback 3 - 4 annual kiddy).

Horse breeding is the branch of animal husbandry in the region, which is considerably lost its economic importance. The horse has replaced by motor vehicles and the importance of horses in transport, agriculture and other activities is becoming smaller. In all countries, European Union increases the growing sport and recreation horse. Number of horses in region Polimlje-Ibar is unsatisfactory about the fact that the total number of horses in 2005 amounted to 3.287. "Growing big of working horse is suppressed, while the breeding of domestic horses mountain out of control the selection department. Even more worrisome is the horse breeding left to mostly private initiative and does not be action plan to regulate the supervision of this particular branch of animal husbandry. Of course, because the interest of the broader public focused on horseracing, equestrian sports and recreation, private initiative is mainly have focus on breeding horses, which correspond to these purposes "[30]. Ivanov [31] finds that certain species and breeds equine animals such as the domestic Balkan mountain horse and donkey, endangered in regarding the maintaining of genotype. Besides, in order to prevent irreversible erosion of genetic diversity and agro-diversity in general, it is necessary to make additional efforts to identify and mark animals. The introduction of an information system for monitoring them, as well as greater support for the activities of preserving of indigenous breeds through rural tourism, marketing implementation and greater valorization products listed species and genotypes. Petrujkić et al [32] reported that the development strategy of horsemanship need to face the facts that in horse breeding invest only wealthy hosts and horse lovers and equestrian sports. For the development of horse breeding in some regions have a tradition of great merit, and gallop and trotting races. By examining the demographic structure of the population trotter in Yugoslavia [33] have established specific demographic parameters, such as the structure of the genotypes in the population, the average age of the offspring, stallions and mares, and the generation interval (with father's and mother's side, and the average generation interval). Mentioned authors stated that harmonizing number of stallions with existing funds mares and their intensive use contributed to the basis of a larger number of offspring to be objective as possible score breeding value stallion. Besides, the definition of the minimum the selection criteria and compulsory licensing would be a requirement for the selection of stallions and mares that could used in reproduction. In that way, it would create the preconditions for quality improvement and numerical increase in population trotter and allow for more efficient selection work, given the long generation interval and poor reproductive ability of the horse as a species.

Exceptionally favorable climatic and vegetation conditions in the region Polimlje-Ibar, hilly terrain with a variety of food for bees, large areas of natural meadows to and pastures, abounds nectar plants, provide favorable natural conditions for the development of beekeeping. "Compared with other more advanced industrial countries in region Polimlje-Ibar have the very clean and healthy nature, which result in the production of high-quality and healthy honey. On the one side in general, we are very poorly represent in the promotion and distribution honey products at the local, thus and at the national level. On the other side the wealth of medicinal plants, whose properties are transfer to honey, allowed the regional Polimlje-Ibar produce the highest quality honeys by nutrients, especially by medicinal properties, such as pelimov honey, honey lime, meadow honey, mountain honey and forest honey. Besides its nutritional and dietetic value of honey has its application in therapeutic 
agents. Honey is remarkable in wound healing, under his influence increases the flow of blood and lymph flow to the wound, has bactericidal properties, it can advantageously used in some type's inflammations of the eyes, for skin diseases, colds, improves digestion, promotes healing of ulcers and strengthens the nervous system [34]. In the observed region, the honey is usually consume for breakfast with bread and tea, and is often us to make pastries (gingerbread), candy, confectioners, ice cream ... Furniture honey in region Polimlje-Ibar is far below the capabilities and natural conditions. The total number of hives of bees in the region in 2005 amounted to 13,073 pieces. According to the Directorate for Development of Small and Medium Enterprises [34], the average yield per hive is about 10 kilograms, while most of the modern beekeeping and gets twice by Bee societies. Honey consumption by capita is also low, at around 0, 26 kilograms per inhabitant. Appears on the market are mainly honey in liquid form and is little honey in honeycombs. Supermarket honey is not having organized in a way that would satisfy producers and consumers. In the retail, prices are at the level of European countries or even above that.

\section{CONCLUSIONS}

Our the research evidence, based on similar researches Đekić [35] and Kljajić et.al. [36] pointed out is in the forefront, several important conclusions, which are based on providing conditions for achieving better results in livestock region Polimlje-Ibar, and here primary think about economic, technological and environmental aspects. Hence, it is necessary to:

1. Increase the capacities in livestock breeding measured by the number of heads of cattle and increment per animal. Further, improve racial the structure of livestock, and which can be achieved by with specific economic incentives. Specialized Entrepreneurs holdings for pasture or pasture- livestock farming could with are adequate quality of meat accomplish a significant market production. Pastures and meadows as natural source animal feed are not a limiting factor in livestock production in the region. In the area of economic conditions for long-term stability of the market of meat and meat products, as resource constraints should be count limitation of financial resources. Investing in livestock farms can track, for example, subsidizing interest rates on loans. Real parity price animal feed, of meat and meat products, and solving the problem of insufficient organization of the domestic meat market, order achieved a greater volume of subsidies for livestock production as an important prerequisite for the are improvement of livestock production. Special help to improve cattle breeding provide funds agricultural budget, because possibilities of family farms not sufficiently exploited - especially for financial reasons. Business networking, and vertical integration in the production sector of milk and of meat, with adequate marketing, it is also a prerequisite for development of animal husbandry. It is particularly important linking smaller manufacturers with manufacturing systems with respect for essential standards of quality.

2. Technological aspect of changes in livestock breeding includes not only the application of more modern mechanization but also modern technologies feeding livestock fund respectively modern zoo technical. Primary production is independent from imports and mainly supported on local resources. On the other side dependence on imports is present when it comes to the procurement of the necessary equipment. A possible solution it would be strengthening of domestic production and cooperation with foreign manufacturers of equipment and machinery the necessary for livestock production and animal feed production. Improving livestock production would provide 
larger export of livestock products which is why is necessary support from the state through incentive measures but also meeting the standards of the world market by the product themselves. A higher chance of export livestock products and for increasing livestock production should too sought in implementation of appropriate standards using modern methods of control (HACCP, GAP ...), for track products from the beginning of production to the final consumer. Higher exports would stimulate effect on the producers.

3. Ecological aspects of changes in livestock breeding must include non-infringement of the balance of ecosystems and the rural environment because intensive livestock farming has negative impact on the environment (wastewater, unpleasant odors ...). Then are preserving the genetic diversity of livestock its growing are increases soil fertility and its utilization. Activities of professional services on increasing market production, it is necessary to intensify. Necessary is a further work on the selection breed and wider application of selected breed in production. Education of farmers through education centers focused on their ongoing training, can improve productivity and quality in livestock production. The limitation in this regard is the increasing number of elderly households in rural areas in the region.

4. The process of devastation of rural settlements in the region is very intense. It manifests itself in various forms. In order to stop the negative trends in rural areas of the region needs a new offensive and rural development policy. According to the accepted view of economic theory goal of rural development, is a better valorization of natural resources, their contribution to the increase of wealth and welfare, especially rural residents, as well as society as a whole. European experiences in rural development policy should be lesson, adjusted to local resources and initiatives [37].

Finally, "The role of the village and agriculture must be first-rate because are their potential major development force the region's future". This requires radically new attitude of society and science, towards the village and agriculture. Instead of the former quartermaster, approach in which they viewed as preventive manufacturers of cheap food has to develop a new concept, a comprehensive rural development, which shall to base on demographic, natural, economic and socio-cultural resources [38].

\section{References}

[1] Rajović G., Bulatović J., International Research Journal of Life Sciences 1(2) (2013) $1-18$.

[2] Rajović G., Bulatović J., Scientific Electronic Archives 5(1) (2014) 5-21.

[3] Rajović G., Bulatović J., Middle-East Journal of Scientific Research 18(3) (2013) 382-388.

[4] Arsić S., Kljajić N., Savić M., Organic livestock Development in the mountains in Golija (2010), Available from: http://www.agroekonomija.wordpress.com (29.01 2014).

[5] Rajović G., Bulatović J., Open Journal of Social Science Research 1(7) (2013) 169-173.

[6] Rajović G., Bulatović J., International Letters of Natural Sciences 1 (2014) 33-53.

[7] Regional Business Centre Berane, Profile municipality of Berane (2004), Available from: http://www.nasme.me (30.01 2014). 
[8] Regional Business Centre Berane, Profile municipality of Plav (2004), Available from: http://www.nasme.me (30.01 2013).

[9] Rajović G., Bulatović J., Russian Journal of Agricultural and Socio - Economic Sciences 5(5) (2012) 3-16.

[10] Kostrovicki I., Typologia rolnictwa, Przeglad Geograficzny, Warszawa, 1969.

[11] Kostrovicki I., Some Methods of determining land use and agricultural orientations as used in the Polish land utilization and typological studies, Book 18, Geographia Polonica, Warszawa, 1970.

[12] Jaćimović B., Proceedings of Institute of Geography Faculty of Science 23 (1976) 94-99.

[13] Tyszkiewicz W., Przemiany struktury przestrzennej rolnictwa Polski 1950-1970, Prace Geograficzne, Ig and PZ PAN, Warszawa, 1978.

[14] Audu Andrew Jatau., International Letters of Social and Humanistic Sciences 8(1) (2014) 18-27.

[15] Emmanuel Tsegha., International Letters of Social and Humanistic Sciences 8(2) (2014) 99-107.

[16] Rowland U. Aleshi, International Letters of Social and Humanistic Sciences 8(2) (2014) 120-129.

[17] Owa W. F., International Letters of Natural Sciences 3 (2014) 1-6.

[18] Bjelajac Đ.Ž., Počuča M., Marković M., Strani pravni život 3(2012) 525-543.

[19] Statistical Office of Montenegro, Census agriculture 2005, Podgorica, 2006.

[20] Rajović G., Bulatović J., International Letters of Social and Humanistic Sciences 1 (2014) 51-62.

[21] Tomić P., Proceedings of the Geographical Institute of the Faculty of Sciences 13 (1984) 11-19.

[22] Jovanović S., Proceedings - Faculty of Geography, University of Belgrade (2002) 131-134.

[23] Arsić S., Mijajlović N., Anđelić B., Status and prospects of agriculture in Goliji with special emphasis on livestock, Monograph, "Golijski cheese ", Belgrade, 2010.

[24] Škorić R., Poultry production in Serbia, Euro-farmer, professional magazine for feeding and breeding animals (2005), Available from: http://www.poljomasine.net (28.01.2014).

[25] Petrujkić T., Veterinary Bulletin 56(1-2) (2002) 11-123.

[26] Radović I., Hog today, Doža Đerđ A.D., for crop-livestock production and trade (2012), Available from: http://doza-djerdj.rs ( 31.01 2014).

[27] Urošević M., Mihajlović Z., Đurić M., Journal Biotechnology in Animal Husbandry 41(1-2) (1987) 23-25.

[28] Agricultural Marketing Information System of Montenegro, Livestock Production (2012), Available from: http://www.amiscg.org (01.02 2013).

[29] Slijepčević S., Ćosović-Medić A., Feasibility study of goat breeding in Bosnia and Herzegovina, "UNDP”, Sarajevo, 2011. 
[30] Trajilović R., Current trends in horse breeding and selection, Faculty of Veterinary Medicine, University of Belgrade and the Ministry of Agriculture, Forestry and Water Management of the Republic of Serbia, Belgrade, 2011.

[31] Ivanov S., Indigenous breeds conservation efforts in the Stara Planina Mt. area, Conference on Native Breeds and Varieties as part of Natural and Cultural Heritage, Book of Abstracts, Šibenik (2011) 113-114.

[32] Petrujkić T., Miljković V., Mrvošić G., Vuković D., Veselinović S., Trivicki G., Bojkovski J., Popović N., Ivkov V., Radojčić S., Conditions horse playing in Yugoslavia and establishment of breeding mares capabilities, Proceedings of horsemanship development program of Yugoslavia, P.P. "Zobnatica" - Subotica, 1996.

[33] Ranković M., Mijatović M., Journal Modern agriculture 48(1-2) (1998) 77-81.

[34] Development of Small and Medium Enterprises of Montenegro, Integrated Development of beekeeping in Montenegro, project-bee (2004), Available from: http://www.nasme.me (22.01 2014).

[35] Đekić S., Journal of Contemporary Agriculture 56(1) (2007) 151-157.

[36] Kljajić N., Arsić S., Savić M., Livestock as a development opportunity for Serbia (2011), Available from: http://www.agroekonomija.wordpress.com (26.01 2014).

[37] Gulan B., Radojević V., The future of rural areas in Serbia, Proceedings of the international conference "Multifunctional Agriculture and Rural Development", Belgrade, (2005) 69-70.

[38] Institute for the Study of the village Belgrade, About us (2013), Available from: http://www.proučavanjesela.rs (30.01 2014). 